\title{
DNA-BASED GOLD NANOPROBE BIOSENSOR TO DETECT PORK CONTAMINANT
}

\author{
R. Ardhiyana ${ }^{1,2, *}$, L. Haditjaroko ${ }^{1}$, S. Mulijani ${ }^{3}$, R.A. Wicaksono ${ }^{4}$ \\ and R. Ranasasmita ${ }^{2}$ \\ ${ }^{1}$ Department of Agroindustrial Technology, Bogor Agricultural University, \\ Bogor-16680, Indonesia \\ ${ }^{2}$ The Assessment Institute for Foods, Drugs And Cosmetics, The Indonesian Council of Ulama \\ (LPPOM-MUI), Bogor-16161, Indonesia \\ ${ }^{3}$ Department of Chemistry, Bogor Agricultural University, Bogor-16680, Indonesia \\ ${ }^{4}$ Department of Agroindustrial Technology, Djuanda University, Bogor-16720, Indonesia \\ *E-mail : rizka.ard@gmail.com
}

\begin{abstract}
Designing a simple, sensitive, and specific method to detect pork contamination in the food industry remains a major challenge. In the current study, we developed a sensitive thiol-bond AuNP-Probe biosensor that will change color when detecting pork DNA in the Cytochrome B region. The interaction of biosensor and DNA sample is measured by spectrophotometer at $540 \mathrm{~nm}$. The biosensor is made by reducing gold with sodium citrate to produce gold nanoparticle with $39.05 \mathrm{~nm}$ diameter. The AuNP-Probe biosensor (gold nano probe) achieved 16.04 ng DNA/ $\mu$ l limit of detection and $53.48 \mathrm{ng} \mathrm{DNA} / \mu \mathrm{l}$ limit of quantification. The linearity $\left(\mathrm{R}^{2}\right)$ between color absorbance changes and DNA concentration is 0.9916 . The biosensor has a good specificity as it does not cross-react with DNA of chicken and beef. To verify specificity towards the target sequence, qPCR was tested to the target sequence and reacted to the PCR product with the biosensor. The PCR DNA isolate result 2.7 fold higher absorbance compared to pork-DNA isolate alone (without PCR). The sensitivity and specificity of the method show the promising application of the thiol-bond AuNP biosensor in pork-detection.
\end{abstract}

Keywords: biosensor, DNA probe, gold nanoparticle (AuNP), pork meat, qPCR

(C) RASĀYAN. All rights reserved

\section{INTRODUCTION}

Tracing porcine contamination becomes a great issue for the Moslem consumers who are forbidden to consume pork and its derivatives. The DNA-based biosensor is offering more efficient cost, time, and preparation compared to the PCR as the porcine standard testing. This study focused on the design of biosensors containing AuNP that bind to the targeted DNA probes to detect the Cytochrome B gene region (Cyt B) which is a specific gene of pork. The previous study with the same principle has been carried out by Baktavathsalam et al. ${ }^{1}$ who created an AuNP-Probe biosensor for the detection of nucleic acids $E$. coli in the urine of patients. However, that research was generating great value detection limit of $54 \mathrm{ng} / \mathrm{ml}$. Other studies detected the presence of the targeted DNA with the principle of lateral flow nucleic acid and value results of detection limit was $4 \mu \mathrm{g} / \mathrm{ml}$. However, the detection of the target is a synthetic DNA ${ }^{2}$. Another case study, AuNP-Probe biosensor as the detector of pork DNA in samples of the biological material mixture but there is no modification of a probe that binds to AuNP ${ }^{3}$.

This study uses the same design of probe with research which is conducted by Ali et al. ${ }^{4}$ for detecting DNA of pork. The distinguishing thing is the modification of the probe with thiol groups (SH) that would be resulted in stronger binding with AuNP. The targeted DNA then will be amplified by Real Time PCR (qPCR) to produce qPCR product (DNA that has been amplified). Furthermore, qPCR products (amplicons) will be reacted with the AuNP-Probe Biosensor to confirm specifically binding only to the targeted DNA. 


\section{EXPERIMENTAL}

Materials that been applicated on this research are Probe: 567-(5')-ThioMC6SD/TACCGCCCTCGCAGCCGTACATCTC-(3')-591 (IDT USA), $\mathrm{HAuCl}_{4}$ (Wako Japan), Trisodium citrate (Merck), Bovine Serum Albumin (Merck), Tween 80 (Merck), $\mathrm{Na}_{3} \mathrm{PO}_{4}$ (Merck), DNA Surefood Extraction Kit (R Biopharm AG), Dynamo Flash SYBR Green qPCR Kit (Thermo Scientific), the design of two primers can be seen on Table-1, all primers are ordered from IDT USA. Pork, beef, and chicken are bought from the nearest market. Moreover, tools that being used in this research are Particle Size Analyzer (Haribo), Centrifuge Sorval ST16R (Thermo Scientific), spectrophotometer Genova Nano (Jenway), Thermoshaker Heating Block (Ditabis MHR 13), qPCR (Biorad CFX96) and Analytical Balance (Precisa). All instruments are calibrated according to ISO17025 requirements.

Table - 1: The Design of Primer qPCR

\begin{tabular}{l|l}
\hline Items & Sequence $\left(5^{\prime}->3^{\prime}\right)$ \\
\hline Probe (GenBank: GU135837.1) & GATACCCCGAACCAGACGAG \\
\hline Forward primer 1 & CCTCACACGATTCTTCGCCT \\
\hline Reverse primer 1 & GGTGTAGTTGTCTGGGTCTCC \\
\hline Amplicon length primer 1 & 250 \\
\hline Forward primer 2 & GAGGAGCTACGGTCATCACA \\
\hline Reverse primer 2 & AGGGTTGTTGGATCCGGTTT \\
\hline Amplicon length primer 2 & 203 \\
\hline
\end{tabular}

Gold Nanoparticle (AuNP) Synthesis and Conjugation with the DNA Probe

AuNP is synthesized and conjugated with DNA probe according to modification process of Mao et al. ${ }^{2}$ In brief, $100 \mathrm{ml}$ of $\mathrm{HAuCl}_{4} 0.01 \%$ is boiled, stirred, and added with $4.5 \mathrm{ml}$ of Trisodium Citrate $0.1 \%$. Color will change from colorless to red if $\mathrm{Au}$ is transformed to nanoparticles. It will then be conjugated by mixing $98 \mathrm{~mL}$ of DNA probes (1 OD) with $1 \mathrm{ml}$ AuNP 3 -fold, and incubated for 24 hours at $4{ }^{\circ} \mathrm{C}$. Excess of reagent is removed disposing supernatant after $12000 \mathrm{rpm}$ centrifugation for 12 minutes. The red pellet is dispersed in $1 \mathrm{ml}$ of buffer containing $20 \mathrm{mM} \mathrm{Na} 3 \mathrm{PO}$, 5\% BSA, 25\% Tween and 10\% sucrose (pH 7.5).

\section{Determination of AuNP-Probe Biosensor Sensitivity and Specificity}

DNA is isolated from $50 \mathrm{mg}$ of pork according to Surefood Extraction Kit manual. The isolate is serially diluted into $150,125,100,80,60$, and $40 \mathrm{ng}$ DNA / $\mathrm{ml}$ to a total of $20 \mathrm{~mL}$ volume. DNA is denatured for 5 minutes at $95{ }^{\circ} \mathrm{C}$, mixed with $12 \mathrm{~mL}$ of AuNP-Probe, and then hybridized for $65{ }^{\circ} \mathrm{C}$ in 10 minutes. The reaction between AuNP-Probe and pork DNA is measured spectrophotometrically at $540 \mathrm{~nm}$ then LOD and LOQ are determined. Relative standard deviation (RSD) is evaluated by reacting pork DNA (at LOD concentration) with the AuNP probe in 10 replicate. Specificity is evaluated by testing AuNP-Probe biosensor with DNA of chicken, beef and also the mixture of chicken and pork and beef and pork.

\section{Confirmation of Specific AuNP-Probe and Pork DNA Binding}

Previously, the author has chosen one primer (among of two pairs of primer candidates) after evaluating the optimum $\mathrm{Ct}$, annealing temperature, and specificity (data not shown). Primer-Blast was used to design primer which amplicons will overlap with the AuNP probe target within the Cytochrome B gene (GenBank No: KT261429.1). As many as 16.6 ng DNA / $\mu$ l Pork DNA (total volume: $6 \mu$ l) was mixed with ready-to-use Dynamo Flash SYBR Green qPCR Kit and amplified according to the manufacturer instruction. PCR reaction is conducted at $95^{\circ} \mathrm{C}$ for 7 minutes denaturation, and 40 cycles that consist of $95^{\circ} \mathrm{C}$ for 10 seconds (denaturation) and $57.6^{\circ} \mathrm{C}$ for 30 seconds (annealing). Melt curve analysis is done between $57-98{ }^{\circ} \mathrm{C}$ (with $1{ }^{\circ} \mathrm{C}$ increment) for every 5 seconds to detect non-specific amplification. Then the PCR product diluted to pork DNA LOD (previously determined) and it will be reacted with AuNP- 
Probe. The results were compared with pure pork DNA and Non-Template Control (NTC) that is reacted with AuNP-Probe.

\section{RESULTS AND DISCUSSION \\ Characterization of Synthesis Gold Nanoparticle (AuNP-probe)}

Sodium citrate is used as the reducing agent of the metal ion $\left(\mathrm{Au}^{3+}\right)$ into $\mathrm{Au}^{0}$ causing the cation changes in size from a very small size (picometer 10-12) into gold nanoparticles measuring 1-100 $\mathrm{nm}^{5}$. In addition to its function as the reducing agent, sodium citrate also acts as a stabilizer (capping agent). The negative charge of citrate ions will be adsorbed by the surface of the gold nanoparticles so that the gold nanoparticles will repel each other because of their negative charge around the surface ${ }^{6}$ so that it can prevent the aggregation of gold nanoparticles. In this paper, the gold was successfully synthesized to $39.05 \mathrm{~nm}$, which is confirmed by Particle Size Analyzer (PSA). Spectrophotometer measurement showed that AuNP has an optimum absorbance in $528 \mathrm{~nm}$, possibly due to surface plasmon resonance ${ }^{7}$ which produce a red coloring. When AuNP was conjugated with the DNA probe using thiol bond, the optimal absorbance will shift to $540 \mathrm{~nm}$ (Fig.-1).

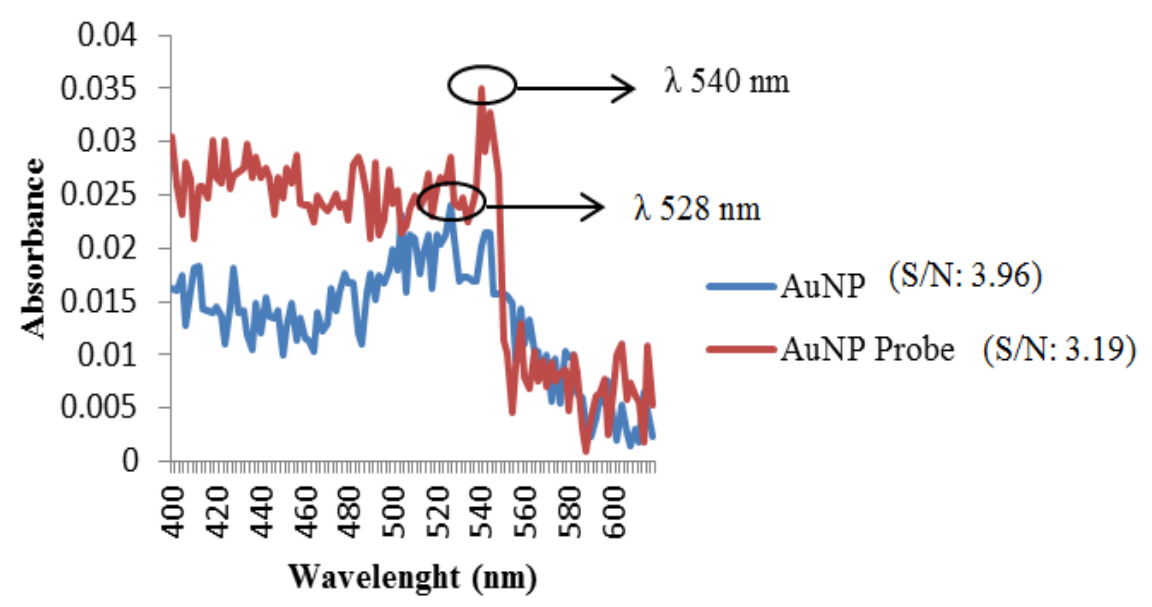

Fig.-1

In this study, materials such as $\mathrm{NaCl}$ or other processing aids are not used in the conjugation process of AuNP and probe. Unlike Shawky et al. ${ }^{8}$ that used cysteamine and CTAB as the processing aids in the conjugation process to obtain optimum aggregation results and resulting in a novelty, this study does not use processing aids. Nonetheless, the induction process of AuNP and probe has successfully bonded. The natural binding system of the AuNP conjugation process with the probe is a simple and universal method which can increase the sensitivity without the addition of other materials or procedures other than the dehybridization process itself ${ }^{9}$. Thiol group at the tip of the probe will be attached covalently to AuNP colloid particles forming an aggregated structure ${ }^{10}$.

\section{Performance of AuNP-Probe Biosensor}

Linearity test was conducted to see the correlation of the concentrations of the targeted DNA in a sample of pork and the absorbance intensity ${ }^{11}$. AuNP-Probe biosensor absorbance (y) were tested against pork DNA serial dilution ( $\mathrm{x}$ ), it will be resulted in $\mathrm{y}=0.0004 \mathrm{x}-0.0124, \mathrm{R}^{2}=0.9916$ (Fig.-2).

This research produces the LOD and LOQ at $16.04 \mathrm{ngDNA} / \mu \mathrm{l}$ and $53.48 \mathrm{ngDNA} / \mu 1$ respectively. This result is much better than Baktavathsalam $e t . a l^{1}$ that has detection limit at $54 \mathrm{ng} / \mu \mathrm{l}$. However, a study by Ali et al. ${ }^{3}$ has the best detection limit at $4 \mathrm{ng} / \mu \mathrm{l}$. The main distinction of this research with the Ali et al. is the modifications of DNA probe with additional thiol groups on the probe tip which expects stronger bond between AuNP and probe. Therefore, thiol groups bind the AuNP with a covalent coordinate bond which results in more specific bond ${ }^{12}$. The relative standard deviation (RSD) of repeatability test is $19.89 \%$ which represents the level of precision measurement at the lowest concentration at 10 repetitions. 


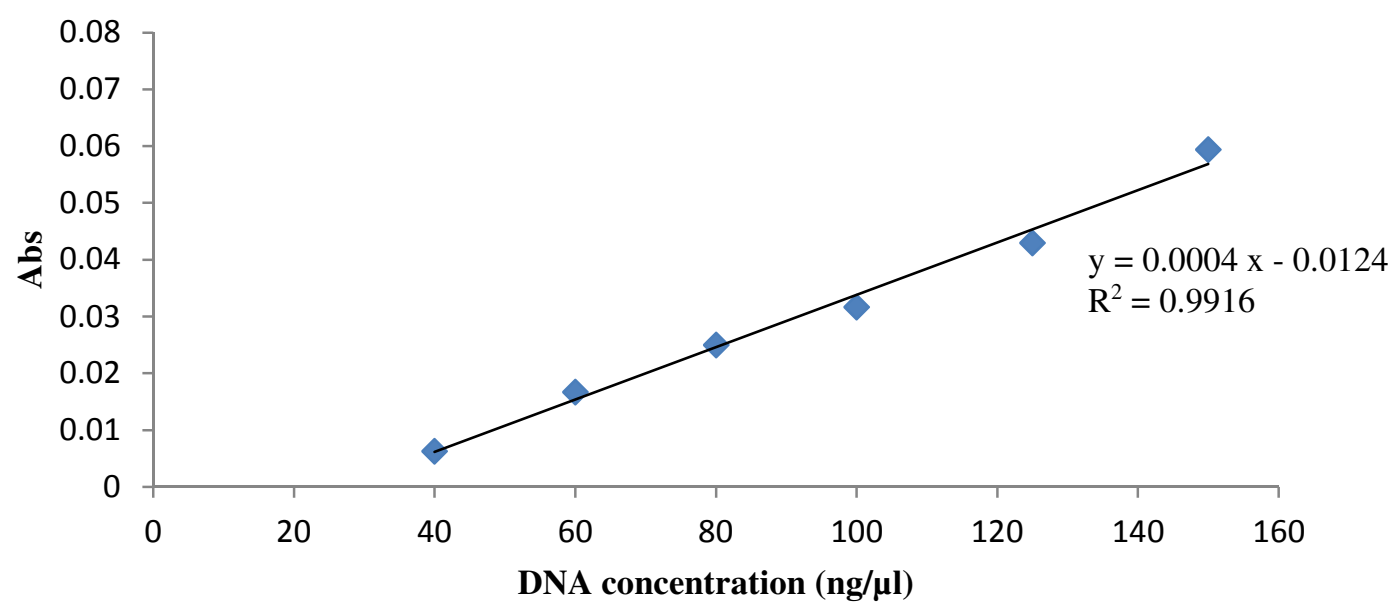

\section{Specificity of AuNP-Probe Biosensor}

Fig.-2

The specificity test is being conducted by testing the AuNP-Probe biosensor upon non pork and mixed pork samples. Fig.-3 shows the difference of intensity absorbance of each sample at a wavelength of 540 $\mathrm{nm}$. Chicken and beef DNA samples do not show positive absorbance values. It indicates the absence of the hybridization process between AuNP-Probe with chicken and beef DNA which is caused by the noncomplementary of the probe (in biosensor) with chicken and beef DNA. In addition, the mixed DNA sample of beef : pork (1:1) has an absorbance value at 0.023 whereas the mixed sample of chicken : pork DNA (1:1) absorbance value is 0.017 .

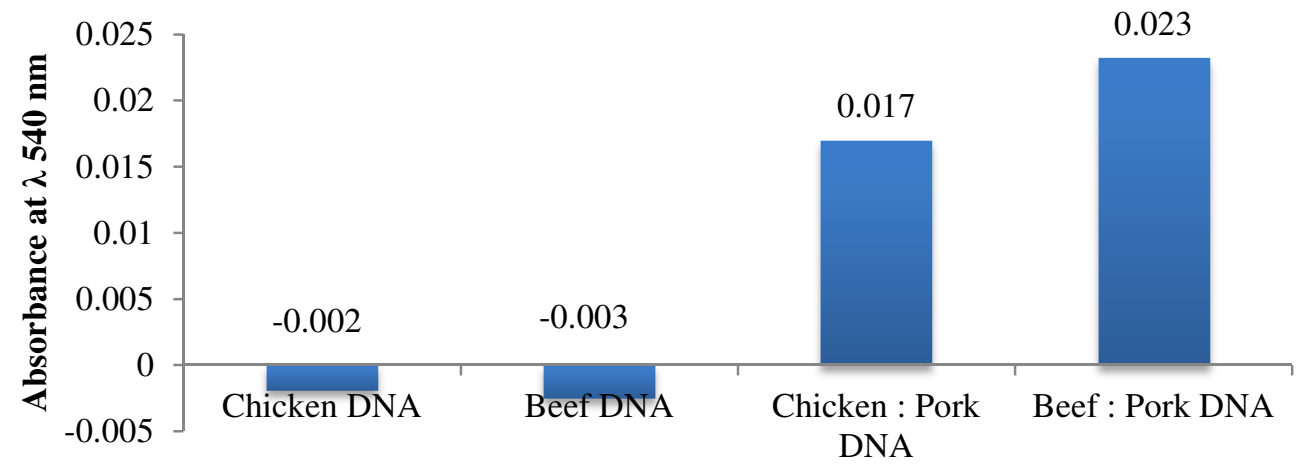

Fig.-3

\section{Specific Reaction Confirmation between the Targeted Sequence and AuNP-Probe using qPCR}

qPCR reaction has successfully amplified the sequence. In the Post PCR step, melt curve analysis shows a single peak curve that confirms the absence of primer-dimer and other non-specific products ${ }^{13}$ (Fig.-4). The PCR product (amplicon) is then tested with AuNP probe biosensor. The result shows the absorbance of the amplicon is 0.041 whereas the absorbance of 2.7-fold of pure DNA is 0.018 . The higher amplicon absorbance values prove the multiplying process of targeted DNA (Cyt B) number after amplification process with qPCR. It is also due to the minimum presence of genomic DNA and other biosensor inhibitors in the amplicon (Fig.-5).

\section{CONCLUSION}

The synthesize AuNP process using citrate method has resulted in AuNP at $39.05 \mathrm{~nm}$. AuNP conjugation with the probe is confirmed by the shift maximum absorbance from 528 to 540 . The performance test of 
AuNP-Probe biosensor generates LOD at $16.04 \mathrm{ng} \mathrm{DNA} / \mu \mathrm{l}$ and LOQ at $53.48 \mathrm{DNA} / \mu 1$. The biosensor does not cross react with chicken and beef DNA samples. The qPCR confirm that the designed probes only interact with the intended target at the Cyt B region on pork DNA. In compare to PCR, AuNP-Probe biosensor method is more efficient in preparation and timing. It is a potential method to detect food adulteration and contamination with pork.
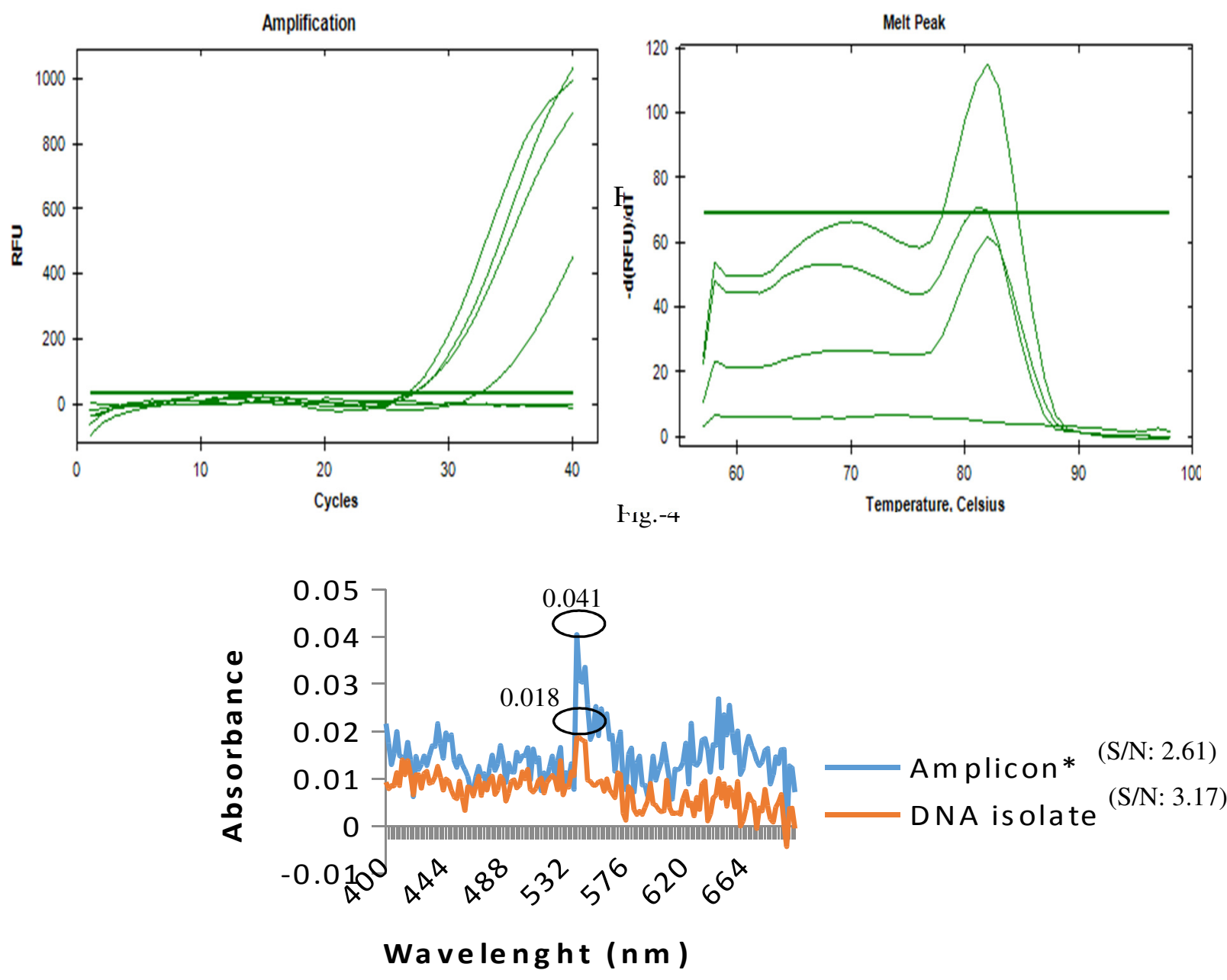

Fig. -5

\section{ACKNOWLEDGEMENT}

This paper is dedicated to one of our co-author, Dr. Reki Wicaksono Ashadi, who passed away on September 16th 2016 during the process of this research. His enthusiasm and warm personality have left a great loss to our heart. The authors express gratitude to Indonesia Directorate of Higher Education for the research fund and Nahdya Khairani for the technical advice.

\section{REFERENCES}

1. P. Bakthavathsalam, V.K. Rajendran, J.A.B. Mohammed, J. Nanobiotech., 10, 8 (2012).

2. X. Mao, M. Yunqing, Z. Aiguo, L. Zhang, L. Zeng, G. Liu, Anal. Chem., 4, 81 (2009).

3. M.E. Ali, U. Hashim, S. Mustafa, Y.B. Cheman, M.H.M. Yusop, M.F. Bari, N. Islam, M.F. Hasan, Nanotech., 22, 195503 (2011). 
RASĀYAN $J$. Chem.

Vol. 10 | No. 3 |1037 - 1042 | July - September | 2017

4. M.E. Ali, U. Hashim, S. Mustafa, Y.B. Cheman, K.N. Islam, J. Nanomat, 103607 (2011).

5. N. Tamam and N. Hidajati, Unesa J. Chem, 3, 40 (2014).

6. A. Tabrizi, A. Fatma, A. Hakan, J. Biol. Chem., 37, 217 (2009).

7. K. Sato, K. Hosokawa, M. Maeda, J. Am. Chem. Soc., 125, 8102 (2003).

8. S.M Shawky, A.M. Awad, W. Allam, M.H. Alkordi, S.F. Elkhamisy, Biosensors \& Bioelectronics, 92, 349 (2017).

9. J.H. Oh and J.S. Lee, Chem. Commun., 46, 6382 (2010).

10. C.A. Mirkin, R.L. Letsinger, R.C. Mucic, J.J. Storhoff, Nature, 382, 607 (1996).

11. Riyanto, Validasi and Verifikasi Metode Uji Sesuai dengan ISO/IEC 17025 Laboratorium Pengujian dan Kalibrasi, Deepublish, Yogyakarta, p. 56-60 (2012).

12. G.T. Hermanson, Thiol Reactions in Bioconjugate Technique, $2^{\text {nd }}$ ed., Academic Press, New York, p. 182,192 (1996).

13. C.J. Wienken, P. Baaske, S. Duhr, D. Braun, Nucleic Acid Research, 39, 8 (2011)

[RJC-1680/2017] 